\title{
Taking it to the Tweet Seats: Using New Technology to Create \\ "Theatre Knowledge-Building Communities" in the English Language Arts and Drama Classrooms
}

\author{
John M. Richardson \\ University of Calgary
}

\section{Author Note}

John M. Richardson, Faculty of Education, University of Calgary.

Correspondence concerning this article should be addressed to John $\mathrm{M}$. Richardson, 199 Powell Avenue, Ottawa, Ontario, K1S 2A4. Contact: jrichardson@ashbury.ca, or 613.236.3340.

\begin{abstract}
The development of digital technology and the participatory culture it engenders presents challenges to secondary school English and drama teachers keen to expose their students to the pleasures and rewards of live theatre. Within Scardamalia's notion of the "knowledge building community” (Scardamalia \& Bereiter, 1994, 2006; Scardamalia, Bransford, Kozma, \& Quellmalz, 2012; Scardamalia, 2002), however, is a framework by which teachers can use educational technology to create authentic, theatre knowledgebuilding communities that allow students to view themselves as engaged participants in the culture of live theatre, while learning valuable $21^{\text {st }}$ century skills.
\end{abstract}

Keywords: theatre; English, drama; educational technology; Scardamalia, knowledge-building community; $21^{\text {st }}$ century skills, youth audience 


\section{Taking it to the Tweet Seats: Using New Technology to Create "Theatre Knowledge-Building Communities" in the English Language Arts and Drama Classrooms}

In Liveness, Philip Auslander's (1999) study of the mediatization of live theatre, he argued against the privileging of theatre over electronic media. After all, a so-called "live" performance is often seen by contemporary audiences in terms defined by film and television, while if the technical supports that underpin a show were removed, the production would soon stop. "Mediatisation," he wrote, "is now explicitly and implicitly embedded within the live experience” (Auslander, 1999, p. 35). Auslander's arguments can now be expanded. In the years since the book's first edition in 1999, the "cultural articulation” (McCarthy, Giardina, Harewood, \& Park, 2003, p. 462) wrought by the Internet revolution has rippled through our lives as well as through theatre auditoriums. Recent debates over whether to install dedicated "tweet seats" in theatres (Taylor, 2012a) are one of the latest signs that even when members of the wireless generation make it into an old-fashioned, flesh and blood theatre, they are often distracted by the "blue glow" (Richardson, 2012) from their portable devices. The theatre has been mediatized, but now so has the audience.

For secondary school English language arts and drama teachers keen to expose students to the pleasures and rewards of live theatre, a number of new challenges, therefore, arise. This paper examines the literature concerning the participatory culture within which many students function, as well as theatres in countries such as Canada, the United States and the United Kingdom. It explores how young people feel about live theatre by considering the results of a focus group of students who attended a series of plays at the National Arts Centre (NAC) in Ottawa, Canada. It then examines Scardamalia's notion of the "knowledge building community" (Scardamalia \& Bereiter, 1994, 2006; Scardamalia, Bransford, Kozma, \& Quellmalz, 2012; Scardamalia, 2002), finding within that framework a way for English and drama teachers to prepare their students for a trip to the theatre. The paper proposes that, by focusing upon collaborative, inquiry-based approaches supported by Web 2.0 technology, educators can create authentic, theatre knowledge-building communities, causing students to view themselves as participants in the culture of live theatre while learning valuable $21^{\text {st }}$ century skills.

\section{The Participatory Culture}

First, let us lift the curtain on some of the remarkable statistics surrounding the mediatized lives of the young people on the school bus heading to the theatre, hanging around the lobby as the lights are dimmed, or sitting in the back row waiting for the play to begin. They spend a lot of time on their devices. Researchers who concluded in 2005 that adolescent use of media devices could not possibly grow beyond an average of 6.5 hours per day were "stunned" to discover in 2010 that the figure had grown to 7.5 hours per day, or 11 hours per days when taking into account multi-tasking (Lewin, 2010). They like to text. Teenagers in the United States, for example, fire off an average of 60 text messages per day (Lenhart, 2012). In addition, they like social media sites. Over three quarters of Canadian teenagers have a social media profile (Ipsos.com, 2009) and if Facebook were a country, it would be the $3^{\text {rd }}$ largest in the world with over one billion users (Williams, 2012). 
These statistics and many others point to the rise of a "participatory culture" (Jenkins, 2009) in which almost half of all teens can be considered media creators (p. 3) instead of mere receivers. Using a multitude of apps, programs, and mobile devices, students "archive, annotate, appropriate, and recirculate media content in new and powerful ways” (p. 8). This includes creating blog or web pages; posting online original artwork, photography, stories, or videos; or remixing online content to create new artworks. The 2005 report The Future of Independent Media (as cited in Jenkins, 2009) confirms that "a new generation of media-makers and viewers are emerging which could lead to a sea change in how media is made and consumed" (p. 12). Not content to sit back and receive cultural content passively, "the people formerly known as the audience" (Rosen, 2006, para. 1) have been raised to expect two-way cultural conversations within a "networked public" (boyd \& Marwick, 2011). This is a site of resistance, creativity, and connection, a place where teens "learn how to manage tensions between public and private, insider and outsider, and frontstage and backstage performances” (Marwick \& boyd, 2010). It is also a site of performance - the performance of self (Litt, 2012).

But as the reshaping and tearing apart of culture takes place-TV shows on iPhones, artists such as deadmau5 mixing and crowdsourcing tracks, venerable magazines such as The Atlantic exhorting readers to connect with web-based content via QR codes, online teens using strategies to attract attention like celebrities-what has happened to theatre, with its fixed, physical infrastructure and its ancient traditions? Auslander sees it locked in a lop-sided struggle for domination with mass media, a struggle that sees theatre "saturated with, and dominated by, mass media representations" (Auslander, 2008, p. 1). Others interpret the influence of new technology in theatre as a creative response to the realities of our digital world, with multimedia theatre reflecting back to the audience in provocative ways the hybrid state of human beings and technology (Dixon, 2007; Klich \& Scheer, 2012; Murray, 2004; Salter, 2010; WardripFruin \& Harrigan, 2004).

Many productions have directly incorporated social media. The Toronto Fringe Festival's “Dina: The Burlapped Crusader” (Taylor, 2012b) in Canada, for example, saw the audience invited to connect with the performer via text, Tweet, Facebook or Tumblr in order to suggest a good retort for a former boyfriend. The Royal Shakespeare Company's production of "Such Tweet Sorrow" was a Twitter version of Romeo and Juliet (Richardson, 2011), and "Purge" at the Contact Theatre, Manchester, UK, had the performer invite audience members on stage to help him "unfriend" members of his Facebook coterie (Beggs, 2013). Productions from cutting edge companies such as the UK's Blast Theory fuse theatre with video games, or movies, or else turn an entire city into a kind of stage in which performers and audience members meet in person or virtually (Blast Theory, 2013), while shows from Canadian director Robert Lepage are also known to combine multimedia elements in highly creative ways. His 2008 production of "The Damnation of Faust" at the New York Metropolitan Opera, for example, saw images on the massive screens behind the performers animated by their voices and movements (Ex Machina, 2013).

Other shows remain more traditional-a theatre, a play, an announcement reminding patrons to turn off their devices and to unwrap cough drops ahead of time so that nothing disrupts the sanctity and impermeability of the fourth wall, darkness- 
although Auslander (2008) would argue that even in these cases the "liveness" of the show is compromised by its many inevitable technological accoutrements. In either case, the teacher-with her class of device-packing, Facebook-posting, texting, mashing, hyperlinking students - is faced with compelling questions. How can she best prepare students for their trip to the theatre, particularly if her school is located in a city that is not home to theatre companies that are experimenting with new technologies in ways that may most obviously appeal to teens? Can live theatre be meaningful to students born and raised in the Web 2.0, participatory culture?

\section{Study Methodology}

These were the questions I had in mind when I met with a focus group of four Grade 12 English students at the end of their four-play, year-long theatre series at the NAC. The plays we saw were chosen to be varied, to be of interest to teens, and were fairly typical of the types of plays that may be available to teachers as they design their program. They were: the light, comic, Tony-award winning musical The Drowsy Chaperone; new versions of A Christmas Carol and Mother Courage and Her Children; and The Comedy of Errors, which riffed comically on rivalry between Montreal and Toronto.The use of a focus group was supported by Cresswell (2007) in that the subjects knew each other, interaction helped yield rich data, and the subjects were co-operative and interested in each other's views (p. 137). Kamberelis and Dimitriadis (2005) agree that focus groups can yield powerful insights (p. 903), while also pointing out the precedent for their use in audience studies research (p. 899), beginning with Morley (2003) in the early 1980s and continuing through the work of scholars such as Radway (1991).

Chris, Ethan, Andrew and Catherine (all pseudonyms) were animated, lively, and opinionated during their 2-hour, semi-structured interview. Those portions of the conversation concerning artworks created by the students in response to the series were presented in English Journal (Richardson, 2012) and focused on how the student responses seemed to reflect eight new mindsets that come from being raised in the wireless world (p. 90). The majority of the conversation was analysed for this paper and grouped into five general categories using the qualitative research methods described by Cresswell (2007). In the data-managing step, I organized the data into three files: focus group, transcript questionnaires, and artworks. In the reading and "memo-ing" stage, I read the transcript and questionnaires several times, forming initial codes for the general themes and developing a list of significant thematic statements. In the describing stage, I described my own experience of seeing the plays as well as the essence of the students' experiences so that the focus of the study could be directed towards the participants' experiences and not my own. In the classifying stage, I wrote a description of what happened, and how the phenomena were experienced in order to explore both their textural and structural aspects. In the representing stage, I wrote a full description of my findings and of how the study was conducted.

\section{Study Findings}

Through an analysis of the transcripts of our conversation, five themes emerge in the students' attitudes toward live theatre, along with a series of questions that teachers may wish to address in their planning. The first theme is that the students' cultural lives 
appeared to be defined and described by digital technology. The students described themselves as living digitally saturated lives in which multi-tasking is the norm. Chris, for example, has a minimum of three windows running while he does homework; Ethan has "tons of windows...like 15 tabs in Firefox, different chats and Skype going on." Even when the information is contained within a textbook, "you feel compelled to look it up on Wikipedia anyway.” Why? Andrew said, “It's just faster and easier.” Chris countered, "Well, sometimes it's not even faster because the page is already there, but you'll flip it open anyway” (Focus Group conversation, 2010).

The busyness continues into the theatre. "I have to admit during Mother Courage I just zoned out and start to-I hate to say, but I was texting with two people the whole time," said Ethan. Andrew agreed. "Yeah," he said, "I think the majority were at one point or another." The students felt that they have short attention spans, better suited to the Web than a theatre (Focus Group conversation, 2010).

The second theme is that prior experience with live theatre appeared to shape the students' perspectives, but this experience was limited. Alone amongst the group, Catherine described herself a keen theatre-goer and a lover of musicals. She suggested that her experience means that she is more likely to enjoy and appreciate a trip to the theatre because she understands, enjoys, and looks forward to its attendant rituals. She enjoys dressing up for a special evening, for example. "It just feels classier," she said. "I like it better than just going to a movie. I like the difference.” Amongst the students, she was most able to identify the meaning of the plays and take pleasure in them (Focus Group conversation, 2010).

Third, as Auslander theorizes, Chris, Ethan, and Andrew tended to see theatre in filmic terms instead of as a separate and unique art form. This lens meant that theatre paled in comparison to film. Ethan summarized the view:

They spend millions and millions and millions of dollars producing a movie. And there's 3D animation in it, there's all that kind of stuff, whereas a play is just on a stage in a building. It just seems so much easier and so much more natural for us to go see movies and enjoy them than to go see plays. (Focus Group conversation, 2010)

Film's realism appeals to the students and they see theatre, which can never match the verisimilitude of the latest computer-generated special effects, as antiquated. Before modern technology, Chris commented, "Your perception of what was the most realistic thing possible was a lot lower than what it is now." Ethan agreed: "It all goes back to what we have available to us ... You have these giant wars going on in these weird planets that are really amazing." Seen in this context, on-stage special effects seem lame. "The guy gets stabbed under his arm, and he's just like 'Ooh,' and fake falls to the ground," Evan said. "But then you'll go see a movie and see the guy get his head blown off." The implicit understanding is that heightened realism is better and that theatrical productions are a very distant runner-up to summer blockbusters (Focus Group conversation, 2010).

Fourth, given their upbringing in the digital milieu, the students prized flexibility, spontaneity, and speed in the cultural and entertainment activities. All four students 
agreed that digital media is more accessible, flexible, and immediate than live theatre, and that their digital lives centre on their laptops and mobile devices. Ethan commented, "It's just so much easier with technology. Facebook, for example, you're connected to just about everybody you know. With a play, you have to actually go somewhere" (Focus Group conversation, 2010). Catherine agreed:

[With the] Internet ... you do it for a short time. However, if you go to the theatre, you have to block off your whole evening ... If you're watching a movie, you can just pause it or stop if you don't like it. The theatre, you don't. (Focus Group conversation, 2010)

The students described a typical evening in which social life, work life, and entertainment were all based around the laptop.

Finally, the students tended to see theatre as old-fashioned. Ethan, Chris, and Andrew saw culture as progressing, as getting better. Ethan reflected upon The Seven Samurai, a film discussed in class, and commented on how what seemed state-of-the-art in 1954 now seemed dated. Theatre fits into the same continuum. Having lost its ability to impress, the boys ranked it alongside a trip to a heritage village or, as Chris commented, theatre is something he does with his grandmother (Focus Group conversation, 2010).

\section{Toward a Theatre Knowledge-Building Community}

For teachers looking for ways in which to engage students such as Ethan, Chris, Catherine, and Andrew, answers may be found in "Knowledge Building" (Scardamalia \& Bereiter, 1994, 2006; Scardamalia et al., 2012; Scardamalia, 2002). A "knowledge building environment is, virtual or otherwise ... [one] that enhances collaborative efforts to create and continually improve ideas” (Scardamalia et al., 2012, p. 8). This definition has implications for the educator who by actively working toward building theatre knowledge allows students to see that theatre is itself a collaborative effort. The playwright, director, designers, cast, crew, administration and finally, but crucially, the audience (the students themselves) work together to create an artistic expression of ideas. The word "create" is also important. The theatre artist, student, and audience all help to create meaning. Finally, the phrase "continually improve ideas" can be reflected in the work of the teacher and the students. By considering drafts of existing texts and by revising their own work, students see in theatre a model for all knowledge creation, such as drafts, comments, new drafts, and rewrites, all of which come before the curtain rises on the final product.

Building upon the constructivist position that argues that students construct their own knowledge, knowledge building recognizes that "creating new knowledge and learning existing knowledge are not very different as far as psychological processes are concerned. There is no patent reason that schooling cannot have the dynamic character of scientific knowledge building” (Scardamalia \& Bereiter, 1994, p. 270). Students live in a knowledge-building world in which the most dynamic sectors such as technology companies, industry, government, and education are themselves knowledge builders. To prepare for that world, students need to move from viewing themselves as knowledge consumers to producers of ideas. 
The production of ideas is reflected in the work of the theatre knowledge builder, who teaches that students are active participants and creators in the world of theatre. Working innovatively with plays prior to driving off in the school bus locates students within the theatre community of scholars and critics. Watching a play places students in the same space as the performers, making them part of the "communal event." Here, student audience members actively engage in the actors' process of interpreting the dramatic text and, ideally, continue to explore their expectations in conversation with each other after the show (Schreiber, 2006).

Students learn that knowledge building is a process, not an end point, and that theatre workers are representative of knowledge economy workers as a whole. Scardamalia and Bereiter (2006) write that "the direct pursuit of idea improvement brings schooling into much closer alignment with creative knowledge work as carried on at professional levels” ( p. 100), a correlation revealed in interviews with theatre workers. Actress Anne Hathaway, for example, has described how she keeps working at improving her craft: "I go to the theatre. I watch Meryl Streep movies. I watch other people's work,"(Rose, 2012) and Judi Dench has commented, "In the theatre you get more chances to have a go at it. Because you do it every night and you adjust things as you go along” (Rose, 2012). Students, like actors, need to see that life in the modern world features a continual drive for improvement, whether in the theatre, the classroom, or in “modern corporations, laboratories (and) design studios” (Scardamalia et al., 2012, p.6).

In traditional classrooms, including language arts classrooms, "there is plenty of discourse ... but it bears little resemblance to the kind that goes on in knowledge-building communities” (Scardamalia \& Bereiter, 1994, p. 273). Most discussion flows through the teacher, following a three-step process: teacher initiates, student responds, and teacher evaluates (Scardamalia \& Bereiter, 1994, p. 273). In a knowledge-building community, the focus is on problems. Inquiry is "driven by questions and desire for understanding," and "engagement is at the level of how things work, underlying causes and principles, and interrelatedness of ideas explored over lengthy periods of time and returned to in new contexts" (Scardamalia \& Bereiter, 1994, p. 274). For the language arts teacher, Scardamalia's words are an invitation to move beyond the traditional, instructionist teaching format. Instead of viewing plays as individual texts to be studied and examined, theatre knowledge building invites teachers and students to examine the work together, to question why the play was written, to understand the relationship between form and content, to see how the play fits within theatre history and the work of the playwright, and to ask how the play has been performed and what challenges it presents to other theatre workers.

In the knowledge-building community, students see their work "as being legitimated by its connection to problems that have commanded the attention of respected scientists, scholars, and thinkers" (Scardamalia \& Bereiter, 2006, p. 98). The field is broad, all encompassing, and welcoming. In creating their own theatrically inspired work, "student-generated theories and models are to be judged not so much for their conformity to accepted knowledge as by their value as tools enabling future growth" (Scardamalia \& Bereiter, 2006, p. 98). Within this dynamic environment, "the Internet becomes more than a desktop library and a rapid mail-delivery system. It becomes the first realistic means for students to connect with civilization-wide knowledge-building and to make 
their classroom work a part of it” (Scardamalia \& Bereiter, 2006, p. 98). Students and teachers use technology because they need to; the classroom connects to the broader world of dynamic knowledge creation. Here the educator is able to lead a dynamic investigation of theatre through activities augmented by the use of technology.

\section{Using Theatre to Build $21^{\text {st }}$ Century Skills}

Scardamalia's most recent writing puts the knowledge-building community model into the context of globalization and the need for nations to innovate or perish. Knowledge building, she writes, helps to forge $21^{\text {st }}$ century skills (Scardamalia et al., 2012). Studying dramatic literature in the context of a theatre knowledge-building community builds $21^{\text {st }}$ century skills with particular effectiveness.

First, it is important to note the centrality of creative thinking to $21^{\text {st }}$ century skills and to the knowledge-building principles. Writing about, watching, creating, and directing drama are creative activities, and therefore, especially relevant to $21^{\text {st }}$ century skills since "processes for innovation need to be supported, celebrated, assessed and shared” (Scardamalia et al., 2012, p. 235). More specifically, the $21^{\text {st }}$ century skills as experienced in knowledge-creating organizations (Scardamalia et al., 2012, p. 269), and the ways in which the language arts teacher can realize them through theatre education are:

1. Creativity and innovation: learning that theatre is the product of a creative process and partaking in the process of theatre-creation.

2. Collaboration/teamwork: understanding that theatre creation is a communal effort and working with diverse partners to understand and create theatre.

3. Information literacy/research: working with technology to gain a deeper understanding of a play's origins, purposes, and the particular issues surrounding performance.

4. Critical thinking, problem solving, and decision making: coming to see that writing and presenting a play presents a range of problems to be solved; practicing problem-solving skills in working out ways to stage a play.

5. ICT literacy: working with technology to build knowledge (see below).

6. Life and career skills: developing an understanding of self as a knowledge creator through active involvement in the field and gaining insight into the lives of theatre professionals.

7. Learning to learn/metacognition: through formative and self-assessment while exploring the text, interpreting the text, and gaining insight into the self as learner and creative thinker.

8. Personal and social responsibility, including cultural competence: gaining insight into how, as a member of this authentic, theatre knowledge community, the individual has a responsibility to others in the creation and understanding of theatre. 
In this approach, the students prepare for their trip to the theatre by creating "epistemic artifacts” such as original scripts, adaptations, costume designs, and production proposals. The student creations make accessible the intellectual life of the community, and reveal the knowledge-building process for examination, comment, and improvement.

\section{From Page to Tweet to Stage: Putting Theory Into Practice}

Making use of the very technology that causes theatres to consider installing "tweet seats," theatre knowledge building allows students to explore plays in innovative and engaging ways while connecting them, and their work, to the broader world of theatrical production. This approach acknowledges that "technologies offer many possibilities for designing richer, deeper, wider-ranging learning activities and assessments” and supports the $21^{\text {st }}$ century learning goal of teaching how to "select and use appropriate technologies during processes such as innovation, communication, collaboration, problem solving and citizenship” (Scardamalia et al., 2012, p. 269).

Some of the ways that educators can use technology to help build a theatre knowledge building community include:

- New online approaches to the text such as apps for mobile devices (CASP, 2007; Engelhardt, 2012), or the Oxford Next Shakespeare project, which provide access to multi-media resources designed to give students a "personal, meaningful and powerful” experience with the play (Oxford University Press).

- Filmed versions of contemporary productions that, together with backstage tours and interviews with directors and actors, can be accessed via projects such as "Digital Theatre," a company that has partnered with five of the UK's leading theatre companies to create and show high-quality video versions of their productions. Digital theatre is used in over 106 countries, the director relating how he receives "glowing emails from African school-teachers, who say that they never believed they would be able to share such performances with their students" (Wade, 2011, p. 57). Access to cutting-edge international productions provides students with compelling evidence that theatre artists are engaging in provocative explorations of the world we live in now.

- Graphic art programs that allow for the creation of costume and design sets, and e-portfolios, and online sharing sites such as Wikis that allow for students to share their work with each other and with professionals in the field.

- Programs such as Skype that can link students to theatre workers, allowing them to understand how professionals make decisions.

- Cloud-based programs such as Google Docs that allow students to collaborate in script-writing and collaborative exploration of the text.

- Constantly evolving web-based resources that draw students into the world of professional theatre and allow for deep engagement, such as the National Theatre's “digital classroom” (National Theatre Resources, 2012), or the Stratford Festival’s online educational resources ("Stratford Festival Games,” 2013). 
Tools such as these allow for the "provision of authentic, rich, dynamic environments.....access to collections of information sources and expertise" (Scardamalia et al., 2012, p. 269), use of collaboration, presentation of events difficult to achieve in the classroom, examples of theatre relationships in action, multiple representations, student manipulation of conventions, student control of the learning process, the opportunity to make student thinking and responses visible, and use of simulations (Scardamalia et al., 2012, p. 269). Together, they help students move from a knowledge "about" theatre, to a knowledge "of" theatre (Scardamalia \& Bereiter, 2006, p. 100). By the time the bus arrives and the students depart for the trip to the performing arts centre, they should feel connected to the world of theatre, understanding of its unique conventions, practiced in some of its skills and eager to immerse themselves in the production.

\section{Conclusion}

Language Arts and Drama teachers seeking to expose their students to the rewards of live theatre performances and dramatic texts have a number of challenges. One of those is the way in which student attitudes toward live theatre may be shaped by their immersion in the digital, participatory culture. However, there is hope for live theatre within the blue glow of PDAs and laptops, and no reason to think that live theatre is doomed to be left behind in the digital dust. Constructivist thinking suggests that students should be given the opportunity to build their own knowledge, and the reality of the $21^{\text {st }}$ century workplace indicates that a focus on knowledge building is most productive. Some could question whether theatre is worth preserving at all, or whether the ancient art form should be left to shrink into tiny enclaves populated by theatre diehards, eclipsed by the wonders of the latest CGI and the laser crisp imagery of the newest "retina" display. David Booth (2003) offers compelling reasons for English and drama to continue placing value on the live experience:

I need for students of all ages to be shocked and surprised by ideas that can only be shared in the safety of the theatre frame; I need the sound of powerful language filling their impoverished word world; I need for them to sense how they and those on stage breathe simultaneously as one; I need to witness the struggle of students of every age participating in drama work, listening to each other as they interact, so that they begin to see that everyone matters if the fiction is to become real; I need to know that my students can read the conventions of theatre as proficiently as they can a Friday night film. I know that theatre can help them to enter their worlds more fully, to see more clearly, and feel and think all at once. I need theatre that will continue to teach them for all their days. (p. 22)

By employing technology within a theatre knowledge-building community, educators and students have the opportunity to build deep knowledge of our rich theatrical tradition while honing their $21^{\text {st }}$ century learning skills and making spaces in the curriculum for the humanity and creative engagement suggested by Booth’s powerful words. 


\section{References}

Auslander, P. (1999). Liveness: Performance in a mediatized culture. London: Routledge.

Booth, D. (2003). Towards an understanding for theatre for education. In K. Gallagher \& D. Booth (Eds.), How theatre educates: Convergences and counterpoints (pp. 14-22). Toronto: University of Toronto Press.

boyd, d., \& Marwick, A. (2011). Social privacy in networked publics: Teens' attitudes, practices, and strategies. Oxford. Retrieved from http://ssrn.com/abstract=1925128Cresswell, J. W. (2007). Qualitative inquiry \& research design. Thousand Oaks: Sage.

CASP (2007). Interactive folio. Canadian adaptations of Shakespeare project. Retrieved May 1, 2013, from http://www.canadianshakespeares.ca/rjfolio.cfm

Ex Machina. (2013). The damnation of faust. Ex Machina. Retrieved May 1, 2013, from http://lacaserne.net/index2.php/opera/the_damnation_of_faust/

Ipsos.com. (2009). What's your child doing on Facebook? Retrieved from http://www.ipsosna.com/news-polls/pressrelease.aspx?id=4437\&wt.mc_id=1110042\&link=4437\&top=

Jenkins, H. (2009). Confronting the challenges of participatory culture. Cambridge.

Kamberelis, G., \& Dimitriadis, G. (2005). Focus groups: Strategic articulations of pedagogy, politics, and inquiry. In N. K. Denzin \& Y. S. Lincoln (Eds.), The sage handbook of qualitative research (3rd ed., pp. 887-907). Thousand Oaks: Sage.

Lenhart, A. (2012). Teens, smartphones \& texting (p. 2). Washington.

Lewin, T. (2010, January 21). Media junkies: Kids wired 7.5 hours a day. The Globe and Mail, p. L3.

Litt, E. (2012). Knock, knock. Who’s there? The imagined audience. Journal of Broadcasting and Electronic Media, 56(3), 330-345. doi:10.1080/08838151.2012.705195

Marwick, A. E., \& Boyd, D. (2010). I tweet honestly, I tweet passionately: Twitter users, context collapse, and the imagined audience. New Media \& Society, 13(1), 114-133. doi:10.1177/1461444810365313

McCarthy, C., Giardina, M. D., Harewood, S. J., \& Park, J.-K. (2003). Contesting culture: Identity and curriculum dilemmas in the age of globalization, postcolonialism, and multiplicity. Harvard Educational Review, 73(3), 449-466. Retrieved from http://www.hepg.org/her/abstract/80

Murray, J. (2004). From game-story to cyberdrama. In N. Wardrip-Fruin \& P. Harrigan (Eds.), First Person: New Media as Story, Performance, and Game (pp. 2-11). Cambridge, Mass.: MIT Press.

Morley, D. (2003). The nationwide audience. In W. Brooker \& D. Jermyn (Eds.), The audience studies reader (pp. 95-111). London: Routledge.

NAC (2013). Teachers \& schools. Retrieved from http://nac-cna.ca/en/education/matinee/englishtheatre-student-matinee

National Theatre Resources. (2012). Retrieved from http://www.nationaltheatre.org.uk/discovermore/digital-classroom 
Radway, J. (1991). Reading the romance: Women, patriarchy, and popular literature. Chapel Hill: University of North Carolina Press.

Richardson, J. M. (2011). "Such Tweet Sorrow": The explosive impact of new literacies on adolescent responses to live theatre. Language and Literacy, 13(1), 98-110. Retrieved from http://ejournals.library.ualberta.ca/index.php/langandlit/article/view/10273

Richardson, J. M. (2012). The blue glow from the back row: Live theater and the wireless teen. English Journal, 102(1), 88-91.

Rose, C. (2012, July 11). Conversations with actresses with Charlie Rose. PBS. Retrieved from http://www.charlierose.com/view/interview/12450

Rosen, J. (2006). The people formerly known as the audience. Pressthink. Retrieved from http://archive.pressthink.org/2006/06/27/ppl_frmr.html

Scardamalia, M. (2002). Collective cognitive responsibility for the advancement of knowledge. In B. Smith (Ed.), Liberal education in a knowledge society (pp. 67-98). Chicago: Open Court.

Scardamalia, M., \& Bereiter, C. (1994). Computer support for knowledge building communities. Journal of the Learning Sciences, 3(3), 265-283.

Scardamalia, M., \& Bereiter, C. (2006). Knowledge building: Theory, pedagogy, and technology. In R. K. Sawyer (Ed.), The cambridge handbook of literacy (pp. 97-115). New York: Cambridge University Press.

Scardamalia, M., Bransford, J., Kozma, B., \& Quellmalz, E. (2012). Assessment and teaching of 21st century skills. (P. Griffin, B. McGaw, \& E. Care, Eds.) Assessment and teaching of 21st century skills (pp. 231-300). Dordrecht: Springer Netherlands. doi:10.1007/978-94$007-2324-5$

Schreiber, M. (2006). Introduction. In T. Rommel \& M. Schreiber (Eds.), Mapping uncertain territories: Space and place in contemporary theatre and drama (pp. 13-14). Trier: Wissenschaftlicher Verlag Trier.

Stratford Festival Games. (2013). Stratford Festival. Retrieved May 1, 2013, from http://www.stratfordfestival.ca/watch/gamesandactivities.aspx?id=71Taylor，K. (2012a, April). Quiet in the audience, please. The Globe and Mail. Retrieved from http://www.theglobeandmail.com/arts/theatre-and-performance/quiet-in-the-audienceplease/article4101599/

Taylor, K. (2012b, July 3). With texts and tweets, the show does go on. The Globe and Mail, p. R1.

Wade, L. A. (2011). The London theatre goes digital: Divergent responses to the new media. Theatre Symposium: A Journal of the Southeastern Theatre Conference, 19, 54-68.

Williams, R. (2012). Revealed: The third largest "country” in the world - Facebook hits one billion users. The Independent. Retrieved from http://www.independent.co.uk/lifestyle/gadgets-and-tech/news/revealed-the-third-largest-country-in-the-world--facebookhits-one-billion-users-8197597.html 